1 Turbulence, displacement, death and worms: a day in the life of a fluvial Carboniferous

2 bivalve

4 Ian A. Kane

6 ABSTRACT

7 In the Pennsylvanian Rough Rock Flags and Rough Rock of northern England, trace

8 fossils attributed to the non-marine bivalve Carbonicola are found. Carbonicola,

9 recorded by Lockeia and associated trace fossils, lived a semi-infaunal lifestyle and thus

10 were influenced by both the sediment in which they were hosted, and the currents which

11 supplied their nutrients and oxygen. A number of palaeocurrent indictors are commonly

12 associated with Lockeia and are confirmed by this study: (a) downstream inclination of

13 vertical burrows; (b) palaeoflow-parallel orientation of long axes. Additional

14 palaeocurrent indicators include: (c) steeper scouring and higher sediment surface on the

15 upstream side; (d) diffuse lamination downstream of the trace, or, more widespread

16 downstream erosion. These semi-infaunal bivalves were partly exposed to the prevailing

17 flow and acted as bed defects, disturbing flow over an otherwise relatively smooth

18 surface; flow separation and acceleration enhanced flow turbulence around the bivalve

19 leading to erosion and the development of a variably developed fan shaped zone of scour

20 immediately downstream. Disturbance and destabilisation of sediment in this way may

21 affect bivalves immediately downstream, plausibly explaining the relatively regular

22 spacing pattern of individual Lockeia, or clusters of Lockeia, exposed on bedding planes

23 and revealed by nearest neighbour analyses. Bivalves that did not survive high energy

24 flow events were either trapped within the sediment, or transported downstream and 
25 deposited in lower-energy environments within the otherwise high-energy deposits of the

26 Rough Rock. These are often associated with Planolites and Cochlichnus, trace fossils of

27 scavenging worms which radiate around the imprints of dead bivalves. This assemblage

28 of trace fossil s indicates that areas suitable for bivalve colonisation occurred in upstream

29 areas.

31 Ian A. Kane [i.a.kane@leeds.ac.uk], School of Earth and Environment, University of

32 Leeds, Leeds LS29JT, UK.

34 Introduction

35 The recognition and interpretation of trace fossils can be critical to our understanding of 36 ancient sedimentary successions, particularly where body fossil preservation is rare.

37 Although tracks, trails and burrows have been recognised in Carboniferous strata since

38 the mid nineteenth century (Binney 1852, on the Westphalian strata of Lancashire), it was

39 the pioneering work on Westphalian strata of Germany which established the relationship

40 of trace fossil assemblages to sedimentary and faunal cyclicity (Jessen 1949; Jessen et al.

41 1952; Seilacher 1963, 1964). Continental invertebrate ichnology has become increasingly

42 important in sedimentary geology, particularly in terms of the interpretation of

43 palaeoenvironmental conditions, and hence prediction of facies associations and

44 distributions, the identification of key stratigraphic surfaces in the absence of temporally

45 distinctive body fossils, and also in our understanding of the evolution, behavioural

46 characteristics and environmental distributions of the trace makers (e.g. Buatois \&

47 Mángano 2004, 2007 and references therein). Bivalves were one of the major trace fossil 48 producers present throughout the Phanerozoic; their environmental adaptability has seen 
49 them conquer a diverse range of habitats during their long evolutionary history (e.g.,

50 Stanley 1970; Eagar 1978; Savazzi 1982; Seilacher 1990).

51 The bivalves trace fossils reported herein belong to a transitional Skolithos-

52 Mermia ichnofacies, being produced dominantly in subaqueous conditions which may be

53 subject to variability in flow conditions and periodic emergence, e.g. channel bars,

54 floodplain areas, crevasse splays (see discussion in Lawfield and Pickerill 2006, and

55 references therein; see also Eagar et al. 1985, p.133 "Scoyenia association").

56 Within the Late-Mississippian and Pennsylvanian of the British Isles, trace fossils

57 attributed to the burrowing, vertical "escape" and horizontal locomotion of bivalves have

58 long been recognised (e.g. Binney 1852, Eagar 1974, Hardy \& Broadhurst 1978, Eagar et

59 al. 1985). Inferences of palaeoenvironmental conditions, including palaeocurrent

60 directions have been made from these. Numerous biogenic sedimentary structures have

61 previously been identified within the Rough Rock and Rough Rock Flags at Cracken

62 Edge, Derbyshire (Hardy 1970; Miller 1986). The present study reports the occurrence

63 and distribution of traces attributed to the non-marine bivalve Carbonicola with the aim

64 of answering the following questions: (1) What features of Lockeia and associated traces

65 are indicators of palaeoflow direction, and what do these features tell us about the

66 hydraulic regime? (2) What factors might induce the observed regular spacing of

67 Lockeia? (3) How are Lockeia associated with other traces? (4) Collectively, can

68 interpretation of these observations provide generic insights for palaeoenvironmental

69 analysis of other systems? (5) Can these insights provide areas for further study of the

$70 \quad$ Rough Rock and Rough Rock Flags?

71 The ichnogeneric name Lockeia is here used, for the hypichnial moulds and 72 epichnial casts interpreted as bivalve resting traces, following the discussion by Maples 
73 \& West (1989). Prior to this, the junior synonym Pelecypodichnus had been used

74 alongside or replacing Lockeia, which was regarded incorrectly as a nomen oblitum. For

75 this reason it should be noted that many of the key papers reported herein refer to

76 Pelecypodichnus rather than Lockeia, but that the two are largely interchangeable.

77 Crucially however, 'Lockeia' does not presume formation through the activity of

78 bivalves, or any other creature, which is an important aspect of the general approach to

79 ichnology.

80

81 Carboniferous Rough Rock and Rough Rock Flags

82 The Carboniferous (Pennsylvanian, Regional Stage: Yeadonian $\mathrm{G}_{1}$ ) (Fig. 1) Rough Rock

83 Flags and the overlying Rough Rock are considered to be the deposits of a progradational

84 fluvio-deltaic system deposited within the Pennsylvanian Pennine Basin of northern

85 England (Heath 1975; Bristow 1987, 1988, 1993; Hampson et al. 1996). The Rough Rock

86 has received much attention over the years (Hull \& Green 1864; Gilligan 1920; Wray

87 1929; Shackleton 1962; Wright 1964; Heath 1975; Bristow 1987, 1988, 1993;

88 Holdsworth \& Collinson 1988; Maynard 1991; Hampson et al. 1996). The pioneering

89 work of Gilligan (1920) on the petrography of the Rough Rock led to his conclusions that

90 deposition was from fluvio-deltaic systems analogous to the modern Mississippi, Ganges

91 and Brahmaputra Rivers under a monsoonal climate, with sediment sourced from a

92 distant northern granitoid gneiss with additional metamorphic and sedimentary rocks.

93 These ideas were refined by Heath (1975) who suggested that the major Rough Rock

94 channels were braided with extensive crevasse splay and overbank deposits. Bristow

95 (1993) describes the Rough Rock as a coarse-grained multi-storey, multi-lateral braided 
96 river sheet sandstone and also proposed the Brahmaputra (Jamuna) River (Bangladesh) as

97 an analogue.

98 The underlying fine-grained sandstones and siltstones of the Rough Rock Flags

99 have received less attention, although they occur at the approximate stratigraphic level of

100 the better known Upper Haslingden Flags (Collinson \& Banks 1975; Collinson 1988)

101 (Fig. 1). Typically, the Rough Rock Flags consist of variably well-developed coarsening

102 upwards packages. South of the present study area, at Ridgeway, Bristow (1988)

103 describes the Rough Rock Flags as consisting of alternating fine-grained ripple laminated

104 sandstones and siltstones, laterally extensive and of consistent thickness over tens of

105 metres. At Cracken Edge, Miller (1986) described the unit as fine-grained cross-

106 laminated and planar-laminated sandstones; further north, at Elland, a similar facies

107 association is overlain by minor coarse-grained channel sandstones within the Rough

108 Rock Flags. Bristow (1988) describes a southwards fining of the Rough Rock Flags with

109 the deposits interpreted as that of a lobate, fluvial dominated delta, analogous to the

110 modern Atchalafaya Delta, USA.

111 The study area, Cracken Edge (Fig. 1), is a north-south trending escarpment

112 dominated by the quarried Rough Rock and underlying Rough Rock Flags which are

113 exposed discontinuously over a distance of $5 \mathrm{~km}$. Cracken Edge runs along the eastern

114 face of Chinley Churn, a 451m high hill between Birch Vale and Chinley in the High

115 Peak of Derbyshire. The principal exposures are Cracken Edge Quarry (disused) and

116 Foxholes Clough $1 \mathrm{~km}$ to the north. The underlying sequence is exposed in the valley

117 immediately to the east of Chinley Churn and is marked at the base by shales containing

118 the Reticuloceras gracile marine band. These are overlain by the fluvial Chatsworth Grit,

119 Simmondley Coal, and shales containing the Gastrioceras cancellatum and Gastrioceras 
120 cumbriense marine bands respectively (Maynard 1991; Waters et al. 2008). The Rough

121 Rock Flags and the overlying Rough Rock form Cracken Edge and are overlain by the

122 Gastrioceras subcrenatum marine band marking the boundary between the European

123 Namurian and Westphalian stages.

125 Trace fossil assemblage

126 The Rough Rock Flags feature plentiful trace fossils of the Skolithos-Mermia ichnofacies

127 (Seilacher 1967; Buatois and Mángano 1995, 2004; Lawfield \& Pickerill, 2006)

128 including Planolites, Cochlichnus, Palaeophycus, Didymaulichnus and Lockeia, aspects

129 of which were described at the locality by Hardy (1970) and Miller (1986). Whilst the

130 previous work forms the basis of this study, the observations and interpretations

131 presented herein comprise a comprehensive review of implications for palaeocurrent

132 analysis and certain aspects of bivalve development and behaviour. Lockeia (L. siliquaria

133 James, 1879) of the Yeadonian at Cracken Edge, and other Carboniferous sandstones of

134 northern England have previously been attributed to Carbonicola although shells are

135 rarely preserved (Hardy 1970; Eagar 1974; Hardy \& Broadhurst 1978; Eagar et al. 1985;

136 Miller 1986). However, rare examples of Carbonicola have been found at the tops of sub-

137 vertical trace fossils similar to those described herein, and from similar aged strata

138 (Hardy 1970; Eagar 1974; Broadhurst et al. 1980; Eagar 1983, Eagar et al. 1985). Moulds

139 and casts of bivalve shells are more commonly found, preservation of shell material was

140 probably rare due to the high energy nature of the environment, compaction of the

141 sediment, and dissolution of carbonate within the vados or phreatic zone (e.g., Bridge et

142 al. 1986; Lawfield \& Pickerill 2006). Hardy (1970) suggested that dissolution of bivalve 
143 shells may have provided the carbonate found within the common carbonate concretions

144 within the Rough Rock, although this was disputed by Miller (1986).

146 Lockeia and genetically associated traces

147 Lockeia siliquaria James, 1879

148 These characteristically almond-shaped traces are $8-30 \mathrm{~mm}$ in length, preserved as

149 epichnial hollows and hypichnial expressions, sometimes with a more pointed end, which

150 generally has a common orientation, 'pointing' upstream, based on its preserved

151 relationship to underlying and overlying ripple cross-lamination and trough cross-

152 bedding (Figs. 2 and 3). Rare casts resembling cross-sections through sand-filled bivalve

153 shells are found in some Lockeia traces (Fig. 2). Where more than one trace is found,

154 there may be a strong degree of ellipse (and palaeoflow) parallelism, smaller groups of

155 individuals may form an en-echelon pattern on the bedding plane, again parallel to 156 palaeoflow (Fig. 3).

$157 \quad$ Lockeia may be found clustered on individual bedding planes, with maximum 158 recorded population densities of up to 1000 per $\mathrm{m}^{2}$ (Fig. 3), however they may be 159 associated with smaller groups, although in general terms where one trace is found within 160 a bed it is likely that they there will be associated traces. Large bedding plane exposures

161 reveal a relatively regular spacing pattern, although Lockeia may be 'paired' or found in 162 clusters (Fig. 3). Nearest neighbour analysis, following the technique of Pemberton \& 163 Frey (1984) was applied to Lockeia distributions at two localities (Fig. 3). Within a $200 \times$ $164200 \mathrm{~mm}$ quadrant, the distance from each Lockeia to its nearest neighbour was measured $165(\mathrm{r})$, the sum $(\Sigma \mathrm{r})$ and the mean distance $\left(r_{\mathrm{A}}\right)$ was then calculated (Fig. 3). The mean value 166 is compared with the mean distribution expected in a randomly distributed population $\left(r_{\mathrm{E}}\right)$ 
167 given by: $r_{\mathrm{E}}=1 / 2 \sqrt{ } p$; where $p$ is the density of individuals per unit area. Departure of the

168 observed distribution from a random distribution is given by the ratio $(R)$ of $r_{\mathrm{A}} / r_{\mathrm{E}}$. Where

$169 R<$ unity, the distribution may be aggregated; where $R=$ unity the distribution is random,

170 and where R>unity the distribution is approaching maximum spacing. Distributions

171 varied from conditions approaching uniform spacing (maximum spacing) (Fig. 3A), to

172 aggregated (Fig. 3B). In Fig. 3B it is apparent that clustered or 'aggregated' individuals

173 occur in densely populated bands.

174 Lockeia have a bimodal size distribution, with each mode having a relatively

175 narrow size range: large traces, representing about $20 \%$ of the population, with a mean

176 length and width of $24.1 \mathrm{~mm}$ and $14.8 \mathrm{~mm}$ respectively; small traces, representing about

$17780 \%$ of the population, with a mean length and width of $12.5 \mathrm{~mm}$ and $9.7 \mathrm{~mm}$ wide

178 respectively (100 samples). Large and small traces have mean length/width ratios of 1.6

179 and 1.3 respectively.

180 This trace fossil appears in large numbers within two distinct horizons in the

181 Rough Rock Flags, the lower horizon is laterally extensive covering at least $0.5 \mathrm{~km}$ in the

182 lower section of the quarry (also noted by Miller 1986, his localities 3-9). The preserved

183 extent of the upper unit is truncated by the channelised base of the overlying Rough

184 Rock. In both cases a thin $(80-120 \mathrm{~mm})$ siltstone horizon very rarely containing vertical

185 traces is overlain by thicker fine-medium grained planar-laminated sandstone which is

186 often extensively marked by subvertical burrows, the tops of which are marked by these

187 almond shaped traces. The base of the sandstone has a different character, being poorly-

188 sorted, organic-rich and lacking sedimentary structure (Fig. 4). Epichnial impressions of

189 Lockeia are associated with sub-vertical traces cutting through underlying sediment, and

190 hypichnial expressions on bed bases (Fig. 5). 
193 These Lockeia traces have previously been attributed to resting traces of the unionid

194 bivalve Carbonicola (Hardy 1970; Eagar 1977; Miller 1986); this study finds no reason

195 to disagree. The presence of two distinct size-classes suggests that the bivalves in each

196 class were of approximately the same age. Modern unionids produce larvae which live as

197 a parasite attaching themselves to the gills of fish (Ellis 1978). Whether this mode of

198 dispersal was developed in the Carboniferous is unknown, although freshwater fish

199 became more common and diversified considerably throughout the Carboniferous (Long

200 2007). It is likely that dispersal of larvae was probably more general, utilising currents

201 and settling out of suspension in areas of lower flow energy. This method of distribution

202 is used today by marine bivalves which typically have a planktonic larva known as

203 veliger (Ellis 1978), and often leads to the development of colonies of bivalves of

204 distinctive size-classes. However, planktonic distribution is problematic as a method of

205 reproduction and colonisation in a fluvial regime, as strong currents may wash veliger out

206 to sea, although the lower density of fresh water (relative to sea water) may allow more

207 rapid settling. Today the only freshwater bivalve with a planktonic stage is Dreissena, a

208 comparatively recent coloniser of the freshwater environment (McMahon 1996). In

209 Sphaeriidae, young are kept in brood pouches and extruded in low numbers (6-30) as

210 relatively large miniatures of the adult (Ellis 1978). The bimodal distribution and

211 association with a chaotic organic-rich sandstone deposit, interpreted as a flood deposit,

212 suggests that the colony arrived as mature adults, carried from upstream, and was

213 dominated by one year group, with lesser mature individuals. The 'spread' of larger sizes

214 of Lockeia supports the conclusion that bivalves were transported in flood conditions, and 
215 that progressively a year-class would be found farther downstream. This could lead to

216 entire mature year-classes in upstream localities being represented by only a few

217 individuals, as survivors of an earlier community (Broadhurst, et al. 1980), compared to a

218 younger year class which may be well represented.

219 Eagar (1978) and Hardy \& Broadhurst (1978) recorded ellipse parallelism of

220 Lockeia traces within Lower Westphalian sediments and attributed it to parallel

221 alignment, along the commissural plane, of the bivalve Carbonicola. The larger of the

222 Lockeia type traces commonly have a stronger degree of ellipse parallelism than the

223 smaller traces, perhaps because larger bivalves presented a larger obstacle to flow

224 necessitating alignment; additionally, the data presented in Fig. 3 show that larger

225 specimens tended to be more elliptical. The upstream 'pointing' of Lockeia (Fig. 2) has

226 previously been attributed to the upstream positioning of the inhalant siphon typical of

227 filter feeding bivalves (Eagar 1974, 1977; Wildish et al. 1987; Vincent et al. 1988;

228 Monismith et al. 1990), and agrees with other sedimentary palaeocurrent indicators

229 within the section (Fig. 3A). Additionally, this orientation reduces the risk of inhaling

230 matter that should only ever be exhaled.

231 Spacing of Lockeia analysed using the nearest neighbour technique revealed a

232 combination of aggregated and well-spaced distributions. The technique was not pursued

233 at length as suitably large exposures were not available; and the character of distribution

234 varied greatly on individual surfaces, for example in Fig. 3B clusters of Lockeia appear as

235 'bands' of individuals, presumably related to some sort of flow alignment and flow

236 sheltering. The distribution between clusters and individuals appears to be more uniform;

237 clusters tend to be close-knit groups suggesting that they acted as an individual within the

238 flow, allowing them to shelter and avoid erosion; this is analogous to mussel banks in 
modern marine environments (Gascoigne et al. 2005). The effect of turbulence on

240 individuals and clusters is discussed in a little more detail below. The nearest neighbour

241 technique may therefore work better if clusters of Lockeia were counted as individuals,

242 and the spacing between clusters and individuals be taken into account.

\section{Burrow traces}

245 Sub vertical 'burrows' are common, recorded as sub-vertical and curved endichnia, 246 reaching up to $650 \mathrm{~mm}$ in length (Figs. 4, 5 and 6). Where the bedding plane is exposed,

247 the burrow top of is marked by an epichnial impression and the base by a hypichnial 248 expression (attributed above to Lockeia). The burrows are generally infilled by the same

249 sediment as the host bed, typically fine-medium sand forming menisci laminae, but 250 commonly with small $<1 \mathrm{~mm}$ mudstone flakes, coarser grains and heavy minerals found 251 in the deepest parts. Where burrows are apparently abandoned, it is common for the last 252 stage of fill to be coarser-grained (Fig. 5). The centre of the burrow may be marked by v253 shaped meniscae, cone like in three dimensions, associated with dark-coloured zones of 254 sediment and/or cement; the 'burrow' is a composite of these nested cones. Lamination 255 upstream of the trace is commonly slightly higher than downstream, with lamination 256 warped steeply into the burrow, downstream lamination is generally less steeply warped 257 and returns to horizontal more gradually.

258 The burrow wall, and sediment surrounding the burrow often has a proud 259 weathering profile suggesting differential cementation (Fig. 4). The width of the burrow 260 tends to increase upwards, in some places more rapidly than others. The traces cut 261 through lamination and bedding. In some areas there is a curvature of the entire trace, or 262 part of the trace, which shows slight down-current movement of the trace producer (Fig. 
263 4). In several sections there is a diffusion of lamination immediately downstream of the

264 trace (Figs. 5 and 6). In one particular bed this is a relatively common feature, with the

265 development of diffuse lamination and more heavily scoured surfaces on the downstream

266 side of the traces (discussed in more detail below).

267

268 Interpretation

269 Heath (1975) refers to these traces as 'internally symmetrical vertical burrows' and Miller

270 (1986) terms them 'escape shafts'. Increase in burrow width from the base to the tops of

271 the traces suggests that the bivalves grew in the space of time taken to deposit the bed;

272 however, no discernible trends have been recorded from these traces. Bivalve growth

273 does indicate that sedimentation was relatively slow but episodic and that these are not

274 true escape traces. Bromley (1996) terms such traces 'Equilibichnia' as movement was an

275 effort to keep in equilibrium with the sediment/water interface. Equilibichnia are distinct

276 from Fugichnia which are escape traces and are created in response to a rapid influx of

277 sediment. Additional evidence of these traces representing upwards movement, rather

278 than burrowing, is their length: it is unlikely for bivalves to burrow to $650 \mathrm{~mm}$ depth,

279 Stanley (1970) reported that the deepest burrowers known today reach only $250 \mathrm{~mm}$ and

280 are marine, although M. Amler (pers. comm.) reports estuarine Mya arenaria of the

281 Brittanic coast burrowing down to $400 \mathrm{~mm}$. Ellipse parallelism was interpreted above to

282 represent palaeoflow alignment of bivalves a view which is supported here; alignment of

283 incurrent/exhalent siphons with tidal currents has also been documented from Mya

284 arenaria in tidal flat areas (Vincent et al. 1988). This is an important point in the

285 interpretation that the traces were produced by upwards movement, as the ellipse 
286 parallelism is found wherever sub-vertical traces cut through bedding; there is no obvious

287 reason for bivalves to maintain this alignment beneath the sediment-water interface.

288 Eagar (1977) noted that burrows often commence obliquely, curving upwards to

289 near vertical in their upper parts. Thoms \& Berg (1985) also described basal curvature in

290 much larger traces in the Devonian Catskill Formation (Pennsylvania, USA), which they

291 attributed to forcing by unidirectional currents and sediment accretion on the upstream

292 side. In this case, and apparently those reported by Eagar (1977), it would be reasonable

293 to assume that the curvature is prominent at the base of the trace as currents may have

294 been stronger at earlier times, but through time flow energy waned. Alternatively, growth

295 of the trace maker through time, potentially combined with increasingly ellipsoid shell

296 morphologies, may have provided it with extra stability so that it was progressively less

297 affected by current activity (assuming relatively uniform current velocities).

298 The slightly higher sediment surface and steep scouring on the upstream side of

299 the trace is typical of erosional scour around denser/larger (and hence more stable)

300 objects on a finer grained mobile bed (Allen 1971). Erosion and diffusion of lamination

301 downstream of the traces suggests that the bivalves were locally enhancing flow

302 turbulence. This scenario could lead to destabilisation of bivalves downstream -

303 potentially leading to the relatively regular spacing patterns of Lockeia reported above.

304 This is discussed in more detail below.

306 Turbulence and erosion

307 Evidence of erosion of bivalves is revealed in several palaeocurrent-parallel sections

308 where sub-vertical burrows are exposed. As noted above, extensive subvertical burrows

309 typically occur in parallel laminated, micaceous sandstones, however, in some sections 
310 the sediment downstream of the burrows is either devoid of sedimentary structure, or

311 lamination has become diffuse or highly irregular (Fig. 6). In some cases, there is a

312 repetitive disturbance, i.e., throughout the stratigraphy, of the sediment in the lee of an

313 individual subvertical trace. On bedding planes, similar structures are expressed as low

314 amplitude hummocky surfaces on the lee side of Lockeia. These may have a fan-like

315 shape but are generally indistinct.

317 Interpretation

318 The close relationship between traces and disruption of sediment on their lee sides 319 suggests that the burrow aperture, or protruding bivalve was acting as an obstacle to flow, 320 or bed defect (e.g., Allen 1971). Flow line convergence on either side of the bivalve 321 would cause local acceleration, whist downstream flow separation may enhance 322 turbulence, leading to localised scour around the shell. The effect of the scour is to further

323 induce upstream flow separation and enhance erosion, as part of a positive feedback loop.

324 The result is that a zone of erosion forms, being steep sided upstream of the bivalve but

325 shallowing and flaring out downstream. The fact that some localities seem to have been

326 particularly prone to this, or that the same trace created this effect repeatedly suggests

327 that the bivalves were often close to the threshold limit for the bed shear stress they could 328 withstand, either due to their positioning (e.g., close to an overspill point) or due to

329 disequilibrium between their size/form and the prevailing flow conditions. The

330 enhancement of turbulence in the wake of the bivalve may trigger bed erosion at lower

331 shear stresses than typically required for plane bed erosion.

332 Sediment destabilisation in the turbulent wake of the bivalve may lead to the 333 erosion and entrainment of the bivalves' contemporaries. This potentially could explain 
334 the relatively regular spacing patterns between individual and clusters of Lockeia within

335 large colonies (Fig. 3A). Modern bivalves have developed strategies to avoid acting as a

336 focus of bed scour, including the development of shell ridges (Stanley 1975a, 1975b,

337 1981; Watters 1994), and the ability to burrow to a depth great enough to preclude

338 erosion (Thoms \& Berg 1985).

340 Lateral movement traces

341 Epichnial grooves, 5-6 mm wide with slightly raised ridges on either side of the central

342 furrow are found on the tops of fine-grained sandstone but are relatively uncommon, and

343 only known from fallen blocks (Fig. 7). Lateral movement traces consist of straight to

344 slightly sinuous trails which sometimes cross but never branch. The longest trails seen

345 were just over $500 \mathrm{~mm}$ in length, but this is a product of limited exposure, potentially

346 they are much longer. Some examples show a range of orientations but most are roughly

347 aligned with each other. Similar trails were reported by Hardy (1970), Hardy \&

348 Broadhurst (1978) and Miller (1986).

$350 \quad$ Interpretation

351 These traces are here attributed to the ploughing movement of bivalves in response to a 352 drop in water level. The bivalves most-likely inhabited shallow water environments such 353 as sand-banks, sand-flats or crevasse splay areas, such environments are prone to

354 emergence during low flow stage and changes in river course; during these times the 355 bivalves would need to move to submerged areas. The approximate alignment of traces 356 suggests movement following a receding water-line, such behaviour has been noted in 357 modern day bivalves during drought conditions and reservoir draining (Fig. 9; also see 
358 Lawfield and Pickerill 2006, Fig. 4 C, E, F). The prominent ridges (epichnial

359 expressions) developed in non-cohesive sediment suggest that the sediment was probably

360 sub-aerially exposed for some period and that the bivalves were able to withstand this.

361 Modern day bivalves are able to withstand days or weeks of desiccation (Miller \& Payne

362 1998). Hardy (1970) reported that these trails may cross cut laminae and were made

363 endichnially up to the sediment surface; this has not been noted in the present study but

364 presumably reflects movement from a slightly deeper burrow occupied during times of

365 submergence.

366

367 Death and worms

368 Planolites, Cochlichnus and Didymaulichnus were described by Miller (1986) at Cracken

369 Edge. The present study has found Didymaulichnus to be rare, but Palaeopyhcus is more

370 common, although not reported by Miller (1986). Most typically, these traces occur

371 within finer-grained intervals in the Rough Rock channel bodies, although they do occur

372 to a lesser extent within the Rough Rock Flags (similar to Miller's (1986) Type A facies

373 association). Planolites and Cochlichnus dominate and are commonly found in

374 association with Lockeia; however where Lockeia is widespread, for example on

375 individual bedding planes, they are less common. However, on certain bedding planes,

376 particularly those of relatively fine-grained intervals within the Rough Rock, preserved as

377 hypichnial expressions on sandstone beds, the above assemblage occurs with Lockeia and

378 the two often have an intimate relationship (Fig. 8). Lockeia traces may be of the

379 characteristic almond shape discussed above, or may be gradational to more rounded

380 forms, suggestive of the inferred bivalve trace maker lying on its side, i.e., an imprint of

381 part of the side of the bivalve rather than the narrower ellipse imprint indicative of a 'life- 
382 position'; around these traces, Planolites and Cochlichnus may be particularly abundant,

383 in some cases radiating from a central Lockeia type trace (Fig. 8B-E).

385 Interpretation

386 Hardy (1970) and Eagar et al. (1985) documented the occurrence of this assemblage of

387 trace fossils with Lockeia type traces, and attributed the relationship to the scavenging of

388 dead and decaying bivalves by polychaete worms (Planolites) and probably nematode

389 worms (e.g., Elliott 1985; see discussion in Uchman et al. 2009). A similar assemblage

390 has been recorded from the Lower Cretaceous Tunbridge Wells Sand (southern England)

391 where the relationship was attributed to nematodes or annelids feeding on dead in-situ

392 bivalves (Goldring et al. 2005). This scavenging fauna was truly opportunistic and able to

393 establish itself very rapidly, as they are only found in significant numbers in close

394 association with Lockeia. It is common for such opportunistic faunas to be found in high

395 densities but low diversities (Bromley 1996). Traces of this fauna generally are not

396 present amongst the life assemblages of bivalve traces, with the exception of small

397 numbers of Cochlichnus. It is suggested that the fauna tended to live within quieter

398 environments of the main river channels, feeding off organic material within the

399 sediment. When these quiet areas were inundated during flood events, potentially

400 carrying bivalves, they took advantage of the situation, migrating to scavenge off the

401 dead or dying bivalves. Traces of the scavenging fauna are generally absent in overlying 402 sandstones.

403 This relationship most commonly occurs at the upper interface of finer grained 404 intervals (e.g. the fallen block of Fig. 8) within the more typically coarse-grained Rough 405 Rock braided river facies. The occurrence of Lockeia within this interval suggests that 
406 suitable environments for bivalve habitation occurred in the immediate upstream area. In

407 turn, this suggests that similar environments to that where the Rough Rock Flags

408 accumulated, which were demonstrably suitable for bivalve life, also occurred laterally to

409 the Rough Rock braided river channels, probably as crevasse splays or other marginal

410 environments subject to periodic emergence.

412 Discussion

413 Lockeia are interpreted as the traces of bivalves which lived an semi-infaunal lifestyle,

414 maintaining equilibrium with the sediment-water interface, and able to burrow to shallow

415 depths to avoid erosion from the substrate. A number of features have previously been

416 described as diagnostic of palaeocurrent trend or direction. Parallelism of the

417 commissural planes of bivalves, in response to the prevailing current direction, gives

418 Lockeia its characteristic ellipse parallelism (Eagar 1977; Hardy \& Broadhurst 1978). As

419 such, where enough measurements may be taken to establish a reliable sample

420 population, it may be possible to infer the trend of palaeoflow. In the case of the Rough

421 Rock Flags, the local palaeoflow indicated by alignment of commissural planes and

422 direction of inhalant siphons suggests flow towards the SE. Local sedimentary

423 palaeocurrent indicators (ripple cross-lamination) above and below suggest the same.

424 This is opposed to the typical palaeocurrents reported for the Rough Rock Flags, which

425 suggest flow towards the SW (Bristow 1987, 1988) (although Miller (1986) reported

426 some palaeocurrents towards the east). The sedimentary and ichnological flow indicators

427 may reflect deposition in an area where flow was locally diverging from the axial flow,

428 such as a crevasse splay, or point bar. 
430 burrows may be related to downcurrent forcing of the bivalve; this study confirms that

431 the inclination of burrows is generally linked to the palaeoflow history of the sediments

432 in which they are found, with flow indicated by those swinging from NE to SE. These

433 burrows typically straighten as they reach the upper parts, suggesting either that flows

434 waned through time, or that bivalve growth provided extra stability allowing the bivalve

435 to maintain its position within the sediment. Additionally, Lockeia and associated

436 burrows tend to have steeper scour margins on their upstream side, and in some cases the

437 lamination surface is higher on the upstream trace. Sediment on the downstream side of 438 the trace may be deflated through erosion, or may reflect lower depositional rates 439 associated with increased flow energy and turbulence induced by flow around the 440 bivalve.

441 Erosion of sediment immediately downstream of the trace may occur through the 442 localised enhancement of turbulence as the bivalve acts as a bed defect (Allen 1971); 443 scour further enhances flow separation, turbulence generation and lead to increased 444 scour. This may ultimately lead to erosion of the bivalve from the substrate (Fig. 10A 445 T3). The resultant sedimentary record includes of scour around a bivalve includes diffuse 446 lamination, or even more irregular scour topography, downstream of the burrow (Fig. 6). 447 Although dominantly found as individuals within larger colonies, Lockeia are commonly 448 clustered, either in pairs, or greater numbers; this close association may allow the cluster 449 to behave as a single 'defect' within the flow. For this reason, the spacing pattern 450 between clusters and individuals may be fairly uniform, although within the clusters they 451 may be closely spaced. For this reason, nearest neighbour analysis is problematic, as 452 depending on the focus of the study, bivalves may be 'aggregated' in a palaeoflow 
453 parallel cluster, or uniformly spaced as individuals or smaller clusters (Fig. 10B). The

454 effect of turbulence enhancement is of importance as it plausibly explains the reasonably

455 uniform spacing pattern of individual or clustered bivalves within large colonies.

456 Evidence of bivalves being dislodged from their substrate is abundant (Fig. 5C-D), which

457 is perhaps unsurprising given the periodically high strength flows and the non-cohesive 458 nature of the sediment.

459 The size distribution of Lockeia suggests domination by at least two year-classes,

460 with larger individuals forming a less tightly associated group, suggesting that they may

461 represent several year classes. Such a distribution may be expected in a unidirectional

462 flow regime where transport of individuals is generally downstream; accordingly, older

463 year-classes may be more evenly distributed along a given river length than younger 464 year-classes, so that in a given locality the older year-class would be less well 465 represented. This has been interpreted by other workers to imply high rates of infant 466 mortality (e.g. Eagar, 1978). In contrast, bivalves that live on a stable substrate in fluvial 467 environments may be characterised by colonies of bivalves with much more complex age 468 and size range structures (Payne et al. 1989).

469 Lateral movement traces are rare within the Rough Rock Flags, suggesting that 470 bivalves tended to be submerged at a depth great enough to maintain their position year 471 round. Additionally, traces tend to occur on surfaces that appear to have been subaerially 472 exposed; preservation potential of these surfaces was probably fairly low, as they would 473 be particularly prone to erosion during the arrival of the next flood event.

474 The food source that made this environment attractive to bivalves was most-likely 475 the large quantities of organic material transported by the Rough Rock braided river 476 system. Evidence of this includes thick accumulations of carbonaceous material and 
477 coalified plant fragments at Cracken Edge, and within many Rough Rock outcrops in the

478 inferred upstream area (e.g., Bristow 1987). At Cracken Edge, plant imprints within the

479 Rough Rock are numerous and include Calamites, Sigillaria, Cordaites, Lepidodendron,

480 Stigmaria, Bothrodendron, and Alethopteris. In the Rough Rock Flags, plant fragments

481 are typically comminuted and largely unidentifiable.

482 In quiet backwaters of the Rough Rock river system, in areas such as abandoned

483 channel-fills, polychaete and nematode worms scavenged on decaying vegetation within

484 the sediment, and on the flesh of dead, decaying bivalves transported during flood events.

485 The preservation potential of sedimentary units within sandy braided rivers is generally

486 low (e.g., Ashworth et al. 1999), implying that most bivalves will not be preserved in-situ

487 after their death, but will be reworked along with their host sediment. Planolites, thought

488 to be the trace of polychaete worms, are the predominant trace of this association and

489 often radiate around the Lockeia, which are thought to represent dead bivalves.

490 Nematodes are thought to create Cochlichnus traces, which has been demonstrated

491 experimentally; although there has been some debate that Cochlichnus may also be

492 formed by insects, or insect larvae (Uchman et al. 2009, and references therein). This

493 scavenging association does not occur in the Rough Rock Flags, suggesting that bivalves

494 which were eroded and entrained from their substrate were carried with the main channel

495 flow and deposited either in the channel or carried to coastal areas; however, as suggested

496 above, preservation potential of shell material was probably rare; thus accumulations of

497 dead bivalves are under-recorded in the stratigraphy (e.g., Bridge et al. 1986; Lawfield \&

498 Pickerill 2006). The association suggests that environments similar to those populated by

499 bivalves during Rough Rock Flags times were present during Rough Rock times, and that

500 the Rough Rock Flags is probably a lateral as well as distal equivalent of the Rough 
501 Rock. The existing subdivision is based on lithofacies, but the two lithofacies may simply

502 reflect depositional sub-environments of the same system (Fig. 11).

503

504 Conclusions

505 The bivalves which created Lockeia and associated locomotion trails and subvertical

506 burrows lived an semi-infaunal lifestyle and thus were influenced by both the sediment in

507 which they were hosted, and the currents which supplied nutrients and oxygen.

508 Conclusions are subdivided into those which may be of general importance and

509 applicable to other systems, and those which allow further interpretation of this particular 510 setting.

511 These trace fossils have received scientific attention over the last two centuries

512 but several new insights from this study further demonstrate the importance of these

513 traces in terms of palaeoenvironmental analysis:

515 (1) A number of palaeocurrent indictors are commonly associated with Lockeia and 516 are confirmed by this study: (a) downstream inclination of near-vertical burrows. 517 The angle may hint at sedimentation rates and also the size of the individual. (b)

518 Long axes of Lockeia are commonly oriented parallel to palaeoflow, presumably

519 with inhalant siphons pointing upstream. Additional palaeocurrent indicators 520 include: (c) steeper sided scour and higher sediment surface on the upstream side

521 of the trace; (d) diffuse lamination downstream of the trace, or, more widespread 522 downstream erosion.

523 (2) Enhancement of turbulence by flow around individual or clusters of bivalves may 524 lead to the development of a fan-shaped zone of increased erosion immediately 
downstream; this may lead to disturbance and destabilisation of sediment, and hence other bivalves, downstream. This effect may plausibly explain the relatively uniform spacing pattern of Lockeia and provides an additional $528 \quad$ indication of palaeoflow.

(3) Scavenging of transported bivalves (killed prior to, or during transport) by polychaete and nematode worms, marked by Planolites and Cochlichnus traces respectively which often radiate towards the imprints of dead bivalves. These

535 These conclusions may provide generic insights into systems with similar settings. In 536 terms of the Rough Rock and the Rough Rock Flags, the trace fossils provide further 537 insights into this well-studied system: (a) palaeocurrent analysis of the traces suggests 538 that a significant component of the flow which deposited the Rough Rock Flags was 539 towards the north-east to south-east; this is confirmed by detailed observation of

540 sedimentary current indicators within the section but is counter to previous interpretations 541 of palaeoflow dominantly to the south-west. This may reflect a different source, as 542 postulated for the Haslingden Flags, or may reflect flow divergence associated with 543 overbank flow, crevasse splays or point bars (potentially supported by Miller's 1986

544 data). (b) The occurrence of Lockeia-Planolites-Cochlichnus scavenging horizons within

545 the Rough Rock braided river sandstones suggests that suitable environments for bivalve 546 colonisation existed in upstream localities, suggesting that Rough Rock Flags type facies

547 are probably lateral, as well as distal equivalents to the Rough Rock. 
550 The author would like to thank Dr Andy Johnson for guidance and inspiration during the

551 early stages of this project. Advice from Dr John Pollard is also much appreciated. Mr H.

552 Hallam (Piece Farm) is thanked for access to sites in the vicinity of Fox Holes Clough.

553 The comments and corrections of an anonymous reviewer and M. Amler significantly

554 improved the manuscript for which I am very grateful.

556 References

557 Allen, J.R.L. 1971: Transverse erosional marks of mud and rock: their physical basis and 558 geological significance. Sedimentary Geology 5, 167-385.

560 Binney, E.W. 1852: On some trails and holes found in rocks of the Carboniferous strata, 561 with remarks on the Microconchus carbonarius. Memoirs of the Literary and 562 Philosophical Society of Manchester (second series) 10, 181-201.

564 Bridge, J.S., Gordon, E.A. \& Titus, R.C. 1986: Non-marine bivalves and associated 565 burrows in the Catskill Magnafacies (Upper Devonian) of New York State. 566 Palaeogeography, Palaeoclimatology, Palaeoecology 55, 65-77.

568 Bristow, C.S. 1987: Sedimentology of large braided rivers ancient and modern. $\mathrm{PhD}$ 569 Thesis, University of Leeds, UK.

571 Bristow, C.S. 1988: Controls on the sedimentation of the rough rock group (Namurian) 572 from the Pennine basin of northern England. In Besley, B.M. \& Kelling, G. (eds): 
573 Sedimentation in a Synorogenic Basin Complex: The Upper Carboniferous Of Northwest

574 Europe 114-131. Blackie, Glasgow.

575

576 Bristow, C.S. 1993: Sedimentology of the Rough Rock: A Carboniferous braided river

577 sheet sandstone in northern England. In Best, J.L. \& Bristow, C.S. (eds), Braided Rivers, 578 291-304. Geological Society of London Special Publication 75.

579

580 Broadhurst, F.M., Simpson, I.M. \& Hardy, P.G. 1980: Seasonal sedimentation in the

581 Upper Carboniferous of England. Journal of Geology 88, 639-651.

582

583 Bromley, R.G. 1996: Trace Fossils - Biology, taphonomy and applications, 2nd edn, 384

584 pp. Chapman and Hall, London, UK.

585

586 Buatois, L.A. \& Mángano, M.G. 1995: The paleoenvironmental and paleoecological 587 significance of the lacustrine Mermia ichnofacies: An archetypical subaqueous 588 nonmarine trace fossil assemblage. Ichnos 4, 151-161.

590 Buatois, L.A. \& Mángano, M.G. 2004: Ichnology of fluvio-lacustrine environments:

591 Animal-substrate interactions in freshwater ecosystems. In McIlroy, D. (ed.), The 592 application of ichnology to palaeoenvironmental and stratigraphic analysis, 311-333.

593 Geological Society of London Special Publication 228.

594 
595 Collinson, J.D. \& Banks, N.L. 1975: The Haslingden Flags (Namurian G1) of south east

596 Lancashire: Bar finger sands in the Pennine Basin. Proceedings of the Yorkshire 597 Geological Society 40, 431-458.

598

599 Collinson, J.D. 1988: Controls on Namurian sedimentation in the Central Province Basins

600 of northern England. In Besley, B.M. \& Kelling, G. (eds): Sedimentation in a 601 Synorogenic Basin Complex: The Upper Carboniferous Of Northwest Europe 85-101. 602 Blackie, Glasgow.

603

604 Eagar, R.M.C. 1974: Shape of the shell of Carbonicola in relation to burrowing. Lethaia $605 \quad 7,219-238$.

606

607 Eagar, R.M.C. 1977: Some new Namurian bivalve faunas and their significance in the 608 origin of Carbonicola and in the colonization of Carboniferous deltaic environments. Phil 609 Trans. Royal Soc B, 280, 535-570.

610

611 Eagar, R.M.C. 1978: The shape and function of the shell: a comparison of some living 612 and fossil bivalve molluscs. Biological Review 53, 16-210.

613

614 Eagar, R.M.C., Okolo, S.A. \& Walters, G.F. 1983: Trace fossils as evidence in the 615 evolution of Carbonicola. Proceedings of the Yorkshire Geological Society, 44, 283-303.

616

617 Eagar, R.M.C., Baines, J.G., Collinson, J.D., Hardy, P.G., Okolo, S.A. \& Pollard, J.E. 618 1985: Trace fossil assemblages and their occurrence in Silesian (mid-Carboniferous) 
619 deltaic sediments of the Central Pennine Basin, England. In Curran, H.A. (ed.), Biogenic

620 Structures: Their Use In Interpreting Depositional Environments, 99-149. Society of

621 Economic and Paleontologists and Mineralogists, Tulsa, Oklahoma, USA.

622

623 Elliott, R.E. 1985: An interpretation of the trace fossil Cochlichnus kochi (Ludwig) from 624 the East Pennine Coalfield of Britain. Proceedings of the Yorkshire Geological Society, $625 \quad 45,183-8$.

626

627 Ellis, A.E. 1978: British freshwater bivalve Mollusca. Keys and notes for the 628 identification of the species. Synopses of the British fauna No. 11, 109 pp. Academic 629 Press, London, UK.

630

631 Frey, R.W., Pemberton, S.G. \& Fagerstrom, J.A. 1984: Morphological, ethological and 632 environmental significance of the ichnogenera Scoyenia and Anchorichnus. Journal of 633 Paleontology, 58, 511-518.

635 Gascoigne, J. C., Beadman, H.A., Saurel, C. \& Kaiser, M. J. 2005: Density dependence, 636 spatial scale and patterning in sessile biota. Oecologia, 145, 371-381.

637

638 Gilligan, A. 1920: The petrography of the Millstone Grit Series of Yorkshire. Quarterly 639 Journal of the Geological Society of London 75, 251-294.

640 
641 Goldring, R., Pollard, J.E. and Radley, J.D. 2005: Trace fossils and pseudofossils from 642 the Wealden strata (non-marine Lower Cretaceous) of southern England, Cretaceous 643 Research, 26, 665-685.

645 Hampson, G.J., Elliottt, T. \& Flint, S.S. 1996: Critical application of high resolution 646 sequence stratigraphic concepts to the Rough Rock Group (Upper Carboniferous) of

647 northern England. In Howell, J.A. \& Aitken, J.F (eds), High resolution sequence 648 stratigraphy: innovations and applications, 221-246. Geological Society of London, 649 Special Publications, 104.

650

651 Hardy, P.G. 1970: Aspects of palaeoecology in arenaceous sediments of Upper 652 Carboniferous age in the area around Manchester. Unpublished $\mathrm{PhD}$ thesis, University 653 of Manchester.

654

655 Hardy, P.G. \& Broadhurst, F.M. 1978: Refugee communities of Carbonicola. Lethaia, $65611,175-8$.

658 Heath, C.W. 1975: A sedimentological and palaeogeographical study of the Namurian 659 Rough Rock in the Southern Pennines. Unpublished PhD Thesis, University of Keele, $660 \mathrm{UK}$.

661

662 Holdsworth, B.K. \& Collinson, J.D. 1988: Millstone Grit cyclicity revisited. In Besley, 663 B.M. \& Kelling, G. (eds): Sedimentation in a Synorogenic Basin Complex: The Upper 664 Carboniferous Of Northwest Europe 132-152. Blackie, Glasgow. 
666 Hull, E. \& Green, A.H. 1864: On the Millstone-grit of North Staffordshire and the

667 adjoining parts of Derbyshire, Cheshire, and Lancashire. Quarterly Journal of the 668 Geological Society, 20, 242-267.

669

670 James, U.P. 1879: Description of new species of fossils and remarks on some others,

671 from the Lower and Upper Silurian rocks of Ohio. The Paleontologist, 3, 17-24.

672

673 Jessen, W. 1949: “Augenschiefer”-Grabgänge, ein Merkmal für Faunenschiefer-Nähe im

674 Westfälischen Oberkarbon. Zeitschrift der Deutschen Geologischen Gesellschaft, 101, $675 \quad 23-43$.

676

677 Jessen, W., Kremp, G. \& Michelau, P. 1952: Gesteins-Rhythmen und Faunenzyklen des 678 Ruhrkarbons und ihre Ursachen. Comptes Rendues 3mme Congrès Statigraphie et 679 Géologié Carbonifère, Heerlen, 3, 289-94.

680

681 Lawfield, A.M.W. \& Pickerill, R.K. 2006: A novel contemporary fluvial ichnocoenose:

682 Unionid bivalves and the Scoyenia-Mermia ichnofacies transition. Palaios 21, 391-396. 683

684 Long, J.A. 2007: Rise of Fishes. In Briggs, D.E.G. \& Crowther, P.R. (eds) Palaeobiology 685 II, 52-57. Wiley-Blackwell, London.

686

687 McMahon, R.F. 1996: The physiological ecology of the zebra mussel, Dreissena 688 polymorpha, in North America and Europe. American Zoologist 36, 339-363. 
690 Maples, C.G. \& West, R.R. 1989: Lockeia, not Pelecypodichnus. Journal of Paleontology

$69163,694-696$.

692

693 Maynard, J.R. 1991: Sequence stratigraphy of the Upper Yeadonian of northern England.

694 Marine and Petroleum Geology 9, 197-207.

695

696 Miller, A.C. \& Payne, B.S. 1998: Effects of disturbances on large-river mussel

697 assemblages. Regulated Rivers: Research \& Management, 14, 179-190.

698

699 Miller, G.D. 1986: The sediments and trace fossils of the Rough Rock Group on Cracken

700 Edge, Derbyshire. Mercian Geologist 10, 189-202.

701

702 Monismith, S.G., Koseff, J.R., Thompson, J.K., O'Riordan, C.A. \& Nepf, H.M. 1990: A

703 study of model bivalve siphonal currents. Limnology and Oceanography, 35, 680-696.

704

705 Payne, B.S., Miller, A.C., Hartfield, P.D. \& McMahon, R.F. 1989. Variation in size

706 demography of lotic populations of Corbicula fluminea (Muller). Nautilus, 103, 78-82.

707

708 Pemberton, S.G. \& Frey, R.W. 1984: Quantitative methods in ichnology: spatial

709 distribution among populations. Lethaia 17, 33-49.

710 
711 Savazzi, E. 1982: Shell sculpture and burrowing in the bivalves Scapharca inaequivalvis

712 and Acanthocardia tuberculata. Stuttgarter Beiträge zur Naturkunde Serie A (Biologie)

$713353,1-12$.

714

715 Seilacher, A. 1963: Lebensspuren und Salinitäts-facies. Fortschritte Geologie Rheinland 716 und Westfalen 10, 81-94.

717

718 Seilacher, A. 1964: Biogenic sedimentary structures. In Imbrie, J. \& Newall, N.D. (eds)

719 Approaches to Paleoecology, 296-316. Wiley, New York, U.S.A.

720

721 Seilacher, A. 1967: Bathymetry of trace fossils. Marine Geology 5, 413-428.

722

723 Seilacher, A. 1978: Use of trace fossil assemblages for recognizing depositional

724 environments. In Basan, P.B. (ed), Trace Fossil Concepts, 167-181. Society of Economic

725 Paleontologists and Mineralogists Short Course 5.

726

727 Seilacher, A. 1990: Aberrations in bivalve evolution related to photo- and 728 chemosymbiosis. Historical Biology 3, 289-311.

729

730 Seilacher, A. 2007: Trace Fossil Analysis, 226 pp. Springer-Verlag, Heidelberg, 731 Germany.

732

733 Shackleton, J.S. 1962: Cross-strata of the Rough Rock (Millstone Grit series) in the 734 Pennines. Geological Journal 3, 109-118. 
736 Stanley, S.M. 1970: Relation of shell form to life habits in the Bivalvia (Mollusca).

737 Memoir of the Geological Society of America 125, 296 pp. Boulder, Colorado, U.S.A.

739 Stanley, S.M. 1975a: Adaptive Themes in the Evolution of the Bivalvia (mollusca).

740 Annual Review of Earth and Planetary Sciences 3, 361.

742 Stanley, S.M. 1975b: Why clams have the shape they have: an experimental analysis of 743 burrowing. Paleobiology 1, 48-58.

745 Stanley, S.M. 1981: Infaunal survival: alternative functions of shell ornamentation in the 746 Bivalvia (Mollusca). Paleobiology, 7, 384-393.

748 Thoms, R.E. \& Berg, T.M. 1985: Interpretation of bivalve trace fossils in fluvial beds of 749 the basal Catskill Formation (Late Devonian), Eastern U. S. A. In Curran, H.A. (ed), 750 Biogenic Structures: Their Use In Interpreting Depositional Environments, 13-20. 751 Society of Economic and Paleontologists and Mineralogists, Tulsa, Oklahoma, USA.

752 Uchman, A., Kazakauskas, V. \& Gaigalas, A. 2009: Trace fossils from Late Pleistocene 753 varved lacustrine sediments in eastern Lithuania. Palaeogeography, Palaeoclimatology, 754 Palaeoecology 272, 199-211.

755 Vincent, B., Desrosiers, G. \& Gratton, Y. 1988: Orientation of the infaunal bivalve Mya 756 arenaria $L$. in relation to local current direction on a tidal flat. Journal of Experimental 757 Marine Biology and Ecology, 124, 205-214. 
759 Waters, C.N., Chisholm, J.I., Benfield, A.C. and O’Beirne, A.M. 2008: Regional

760 evolution of a fluviodeltaic cyclic succession in the Marsdenian (Late Namurian Stage,

761 Pennsylvanian) of the Central Pennine Basin, UK. Proceedings of the Yorkshire

762 Geological Society, 57, 1-28.

763

764 Watters, G.T. 1994: Form and function of unionoidean shell sculpture and shape

765 (Bivalvia). American Malacological Bulletin 11, 1-20.

766

767 Wildish, D.J., Kristmanson, D.D., Hoar, R.L., Decoste, A.M., McCormick, S.D. \& White,

768 A.W. 1987: Giant scallop feeding and growth Responses to flow. Journal of 769 Experimental Marine Biology and Ecology, 113, 207-220.

770

771 Wray, D.A. 1929: The Carboniferous Succession in the Central Pennine Area.

772 Proceedings of the Yorkshire Geological Society 20, 228-279.

773

774 Wright, M.D. 1964. Cross-bedding in the Millstone Grit of the Central Pennines and its 775 significance. Geological Magazine 101, 520-530. 

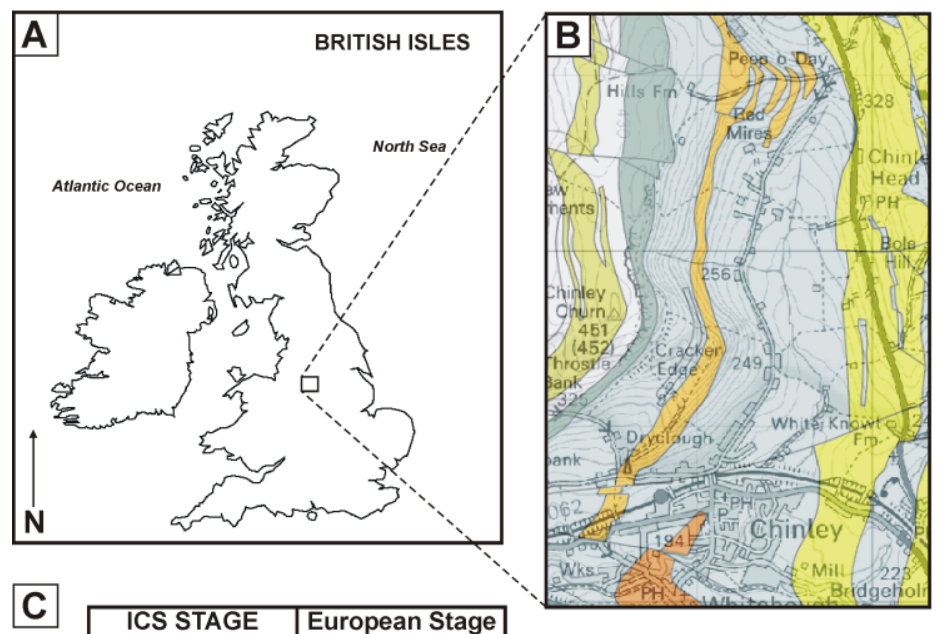

Stratigraphy

Woodhead Hill Rock

Pennine Lower Coal Measures Fm.

Rough Rock

Millstone Grit Group (undifferentiated)

Chatsworth Grit

Roaches Grit

Kinderscout Grit

0
0
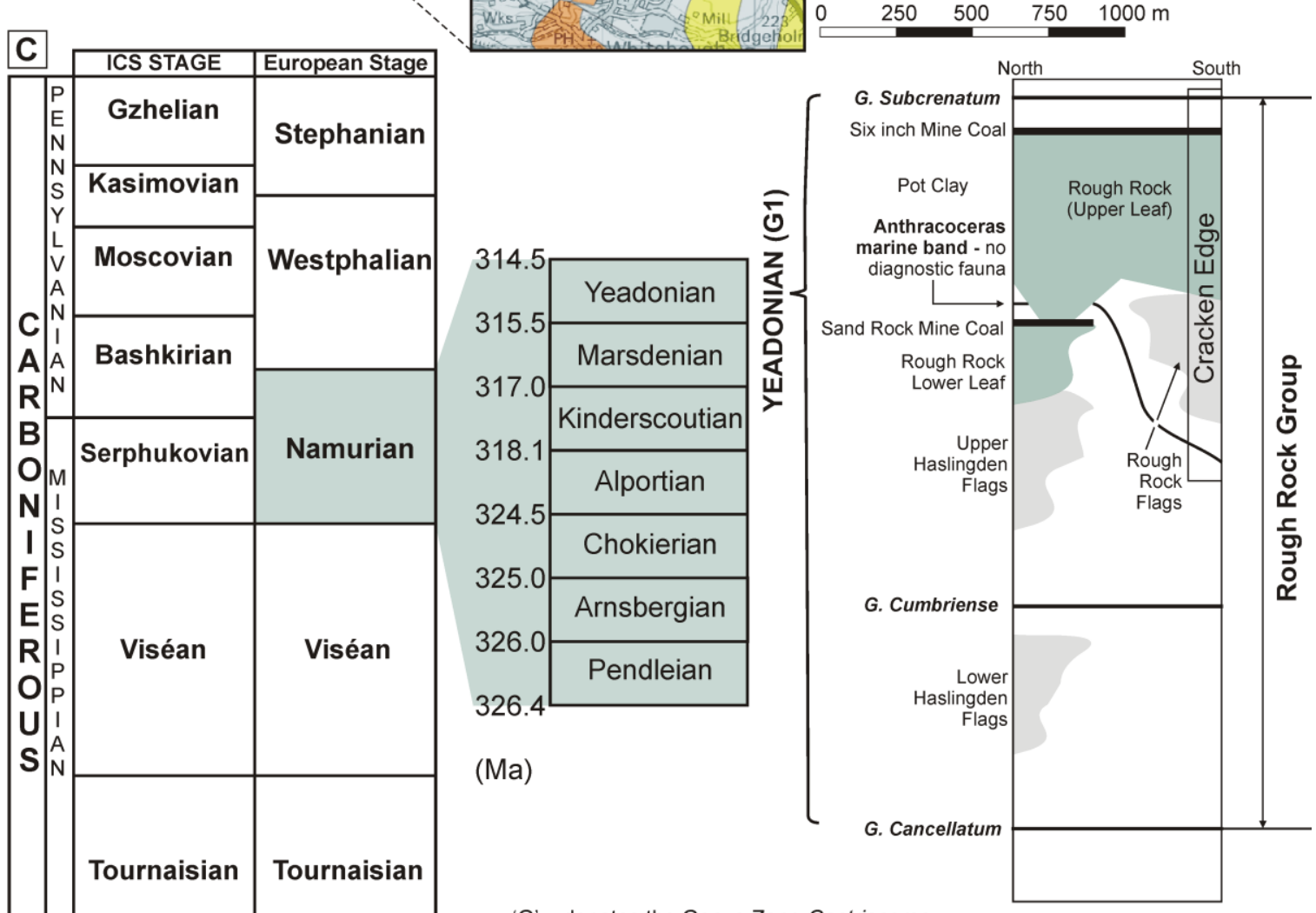

' $G$ ' = denotes the Genus Zone Gastrioceras.

Distinctive thick shelled ammonoid horizons in italics ' $G$ ' = Gastrioceras

Figure 1 - (A) Location of the study are in the UK; (B) Geological map of the area around Cracken Edge, near Chinley in the High Peak of Derbyshire (Geological Map Data@NERC 2009); (C) Stratigraphy of the Rough Rock Group, showing the defining ammonoid zones (Gastrioceras cancellatum and Gastrioceras subcrenatum at the base and top respectively). The location of Cracken Edge is shown schematically. Partly modified from Hampson et al. (1996). 


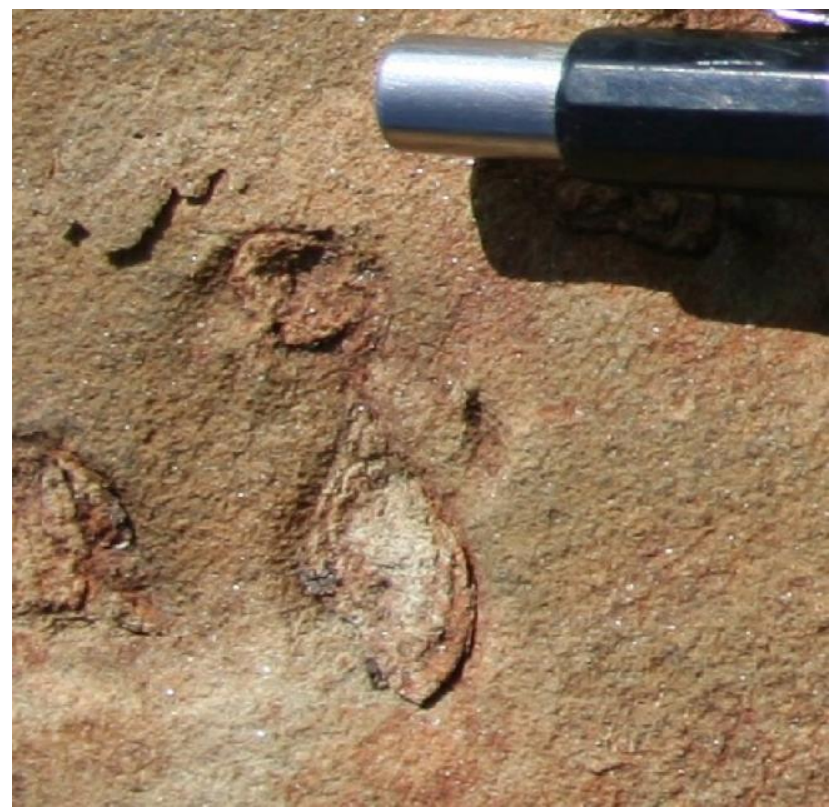

788 Figure - 2. Lockeia epichnial depression with sand-filled cast of bivalve shell. Several 789 specimens are revealed at the tops of burrows (Fig. 5) but no well-preserved examples of 790 the trace maker have been found. Hardy (1970) and Miller (1986) attribute this bivalve to 791 Carbonicola based on its occurrence at other localities. Note the pointed end of the shell 792 (top) marking the position of the inhalant siphon. 

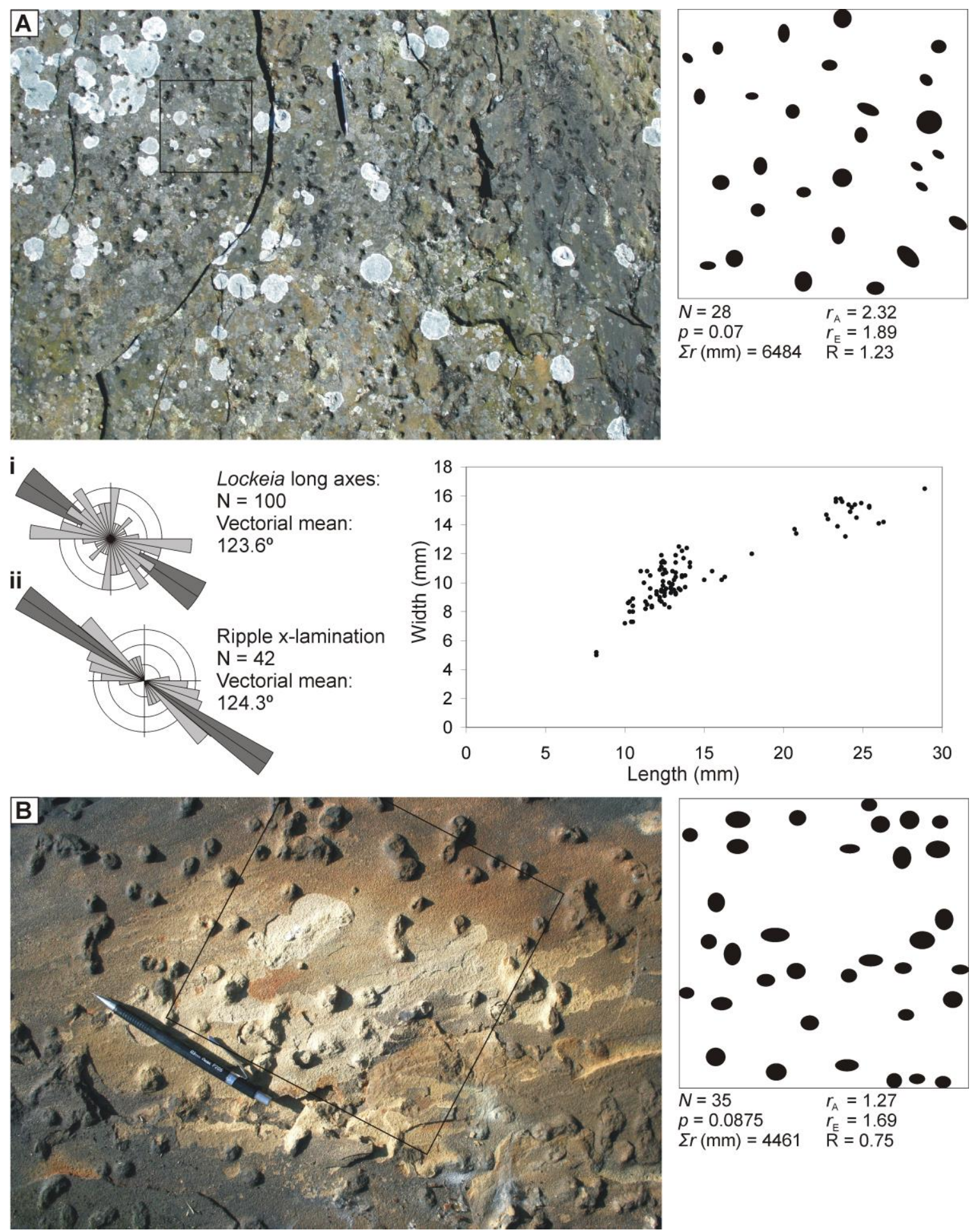

Figure 3 - (A) Lockeia as epichnial impressions (negative traces) on an in-situ upper bedding plane surface, which overlies the subvertical burrows of Fig. 4. Lockeia has a relatively regular spacing pattern; it is however common to find clusters of two or more individuals, often with an 'en echelon' alignment with palaeoflow (see 'i' and 'ii'). Nearest neighbour analyses reveal that Lockeia in has a non-random distribution $799(\mathrm{R}=1.23)$ (values above unity suggests distribution is approaching maximum spacing). 800 Long-axes trend approximately NW-SE, directional information suggests alignment with 801 palaeoflow towards $123.6^{\circ}$. Size distribution analysis reveals two distinct size classes. 
802 (B) Hypichnial expressions of Lockeia with central apertures (on a loose slab). Lockeia 803 also have a non-random distribution but their low value $(\mathrm{R}=0.75)$ suggests that they are 804 aggregated, which is clear to see in the image. Quadrants are $200 \times 200 \mathrm{~mm}$; pencil is $805145 \mathrm{~mm}$ long. Note the central 'apertures' of Lockeia, which may reflect foot withdrawl; 806 these are not a common feature of Lockeia in the present study, although they resemble 807 some of the Lockeia found at the bases of 'escape shafts' illustrated by Broadhurst et al. 808 (1980, Fig. 8).

809

810
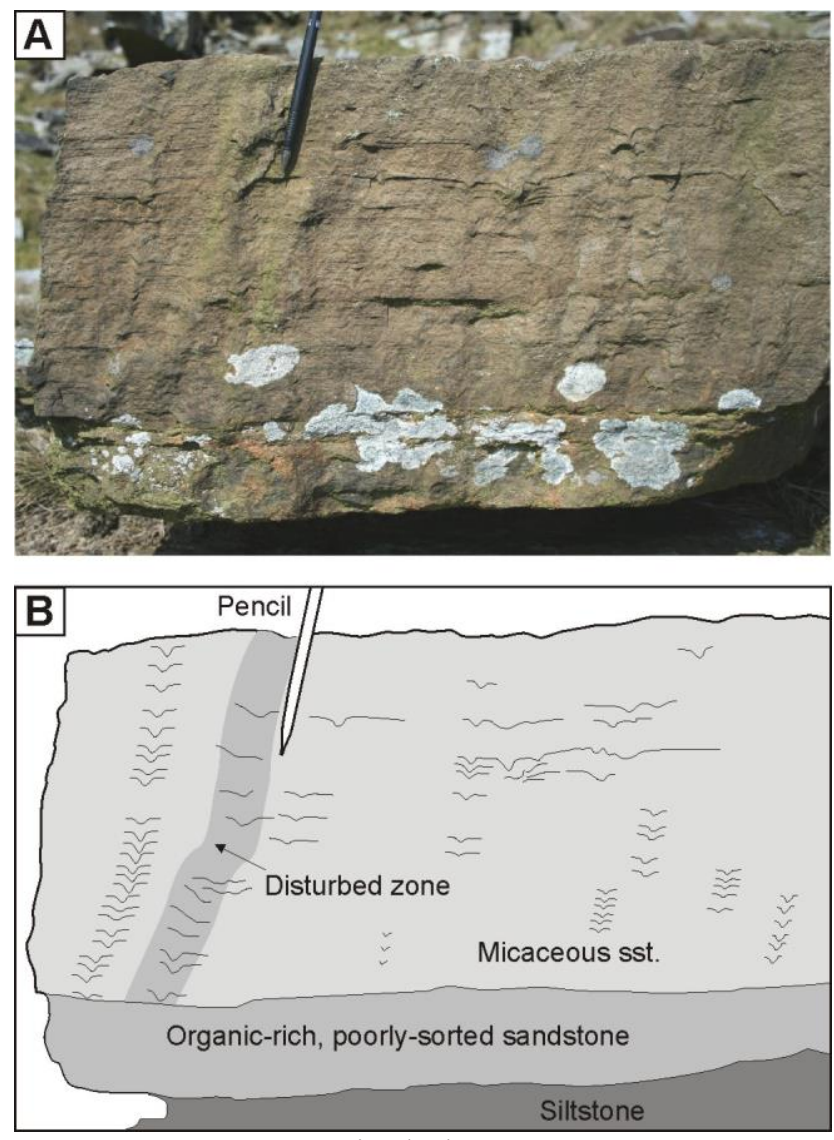

812 Figure $4-$ (A) Vertical 'burrow' traces preserved as endichia, marked at their tops and 813 bases by epichnial and hypichnial Lockeia respectively. Prominent traces are highlighted 814 in (B). These traces are referred to Equilibichnia, as they represent the response of the 815 organisms (bivalves) to episodic sedimentation, rather than true escape traces, or 816 downwards burrowing traces. The traces appear to originate from the organic-rich 

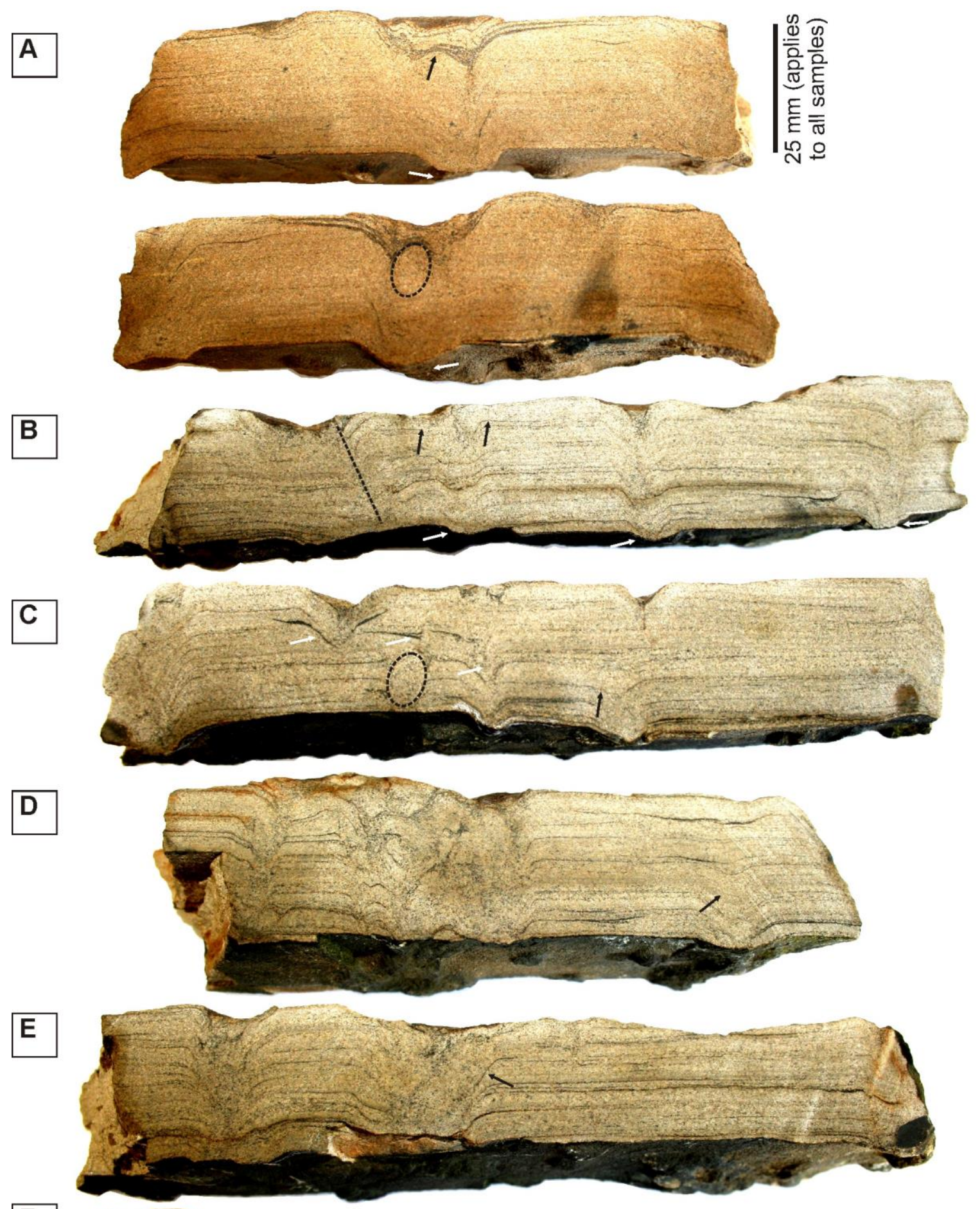

823 Figure 5 - Sliced sections. (A) Opposing sections through Equilibichnia trace associated 824 with hypichnial expression (white arrows) and epichnial impression of Lockeia. In this 
case the bivalve appears to have burrowed into the sediment in response to erosion of the substrate (demonstrated by the scour topography overlying the burrow aperture); this has subsequently been filled by micaceous and muddy sediment; the outline of the sand filled shell is marked by dark-coloured cement (circled in lower image). The protrusion of the bivalve is marked in the top image (black arrow). (B) Sub-vertical burrows with basal Lockeia hypichnial expressions marked (white arrows). Black arrows indicate the change in sediment surface relief across one of the burrows, indicating palaeoflow from right to left. The dashed line indicates downward burrowing of an unknown organism, note sharply down-warped sediment on RHS of line. (C) Burrow arrowed in white suggests progressive downstream dislodging of bivalves; however, it cannot be said for certain whether this is the progressive downstream movement of one individual or more, i.e., successive colonisation surfaces. Note the uppermost white arrow shows a large trace with no apparent underlying precursor. The black arrow points to an abandoned burrow, the relief of which was progressively healed by later flows. Dashed oval line indicates the outline of a sand-filled shell indicating death in-situ (e.g. Broadhurst et al. 1980) (D) Black arrow indicates an abandoned burrow trace. Centre of sample is marked by an intensively burrowed fabric, entirely created by bivalve movement. (E) Steep upstream burrow margin with diffuse laminae and shallow margin on the downstream side. (F) Burrow tops, i.e., Lockeia epichnia, infilled with coarse-granular sand.
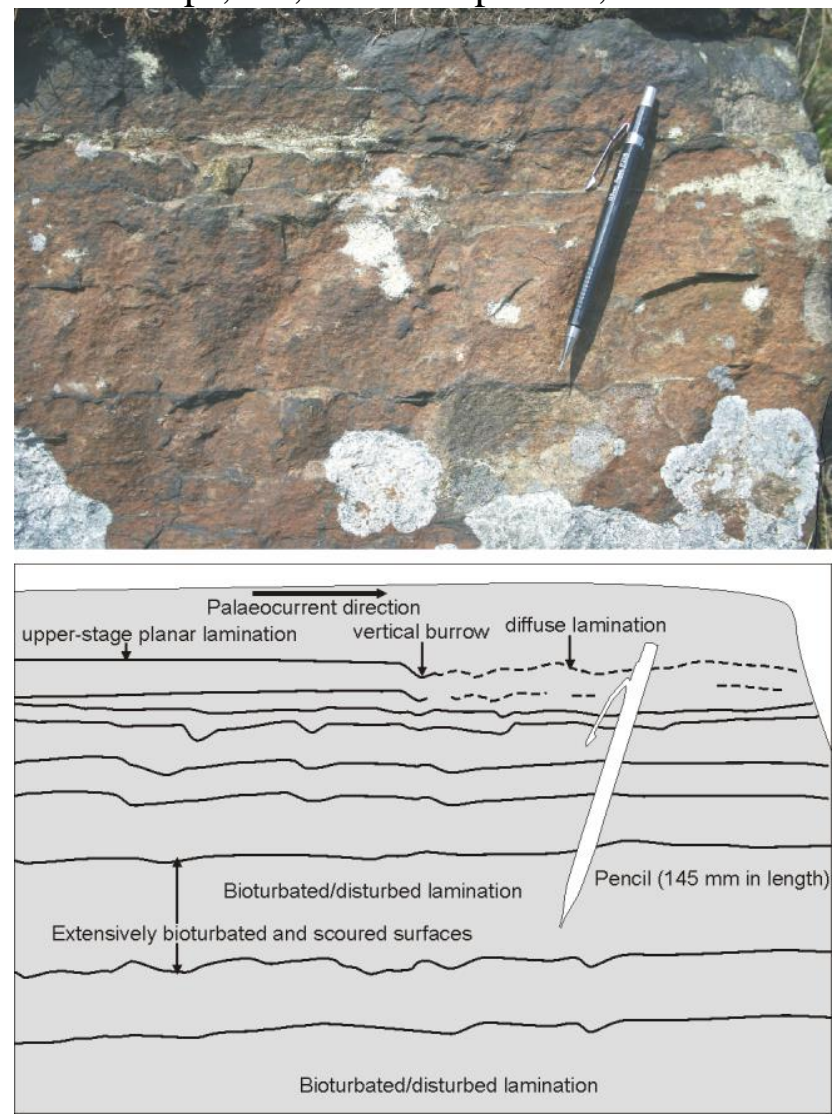

Figure 6 - Relatively impersistent subvertical burrows within an exposure approximately parallel to palaeoflow. There are a number of clear examples of downstream erosion on the lee-side of the vertical traces, which are attributed to bivalve equilibichnia. On the lee-side of the trace, lamination which is clear and defined by micaceous layers on the upstream side, is replaced by diffuse lamination, or an apparently massive appearance. This feature is here attributed to downstream erosion of the substrate. This effect may be 
851 a critical factor in the spacing of bivalves within colonies (Fig. 3). The impersistence of 852 traces in this locality suggests that it was subject to regular high energy flow events 853 (lower $8 \mathrm{~m}$ of the Rough Rock Flags recorded by Miller 1986).

854

855

856

857

858

859

860

861

862

863

864

865

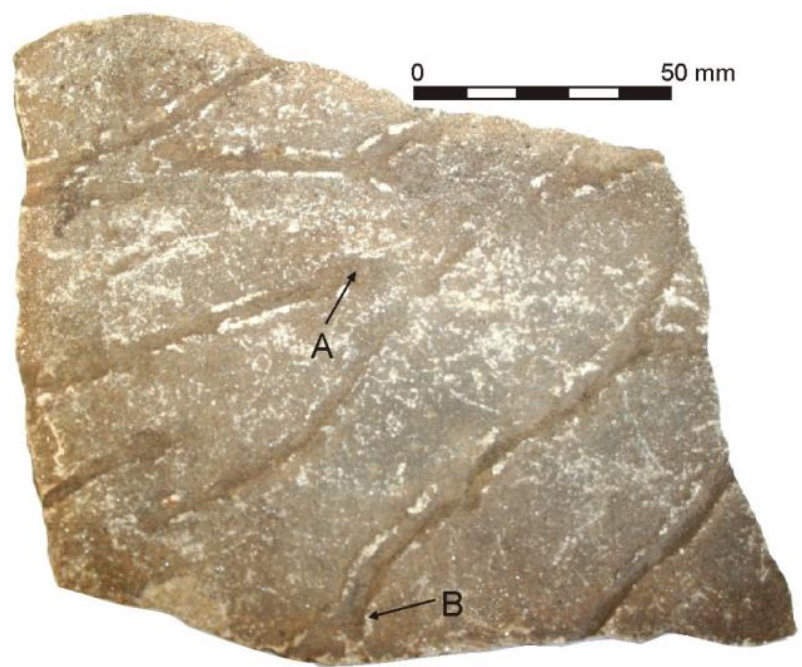

Figure 7 - Locomotion tracks are uncommon at Cracken Edge. These "plough marks" take the form of epichnial grooves, 5-6mm wide with slightly raised ridges on either side of the central furrow, and often terminate in a Lockeia trace (A). Traces are straight to slightly sinuous trails which sometimes cross but never branch, these have only been found on loose slabs from the lower $8 \mathrm{~m}$ of the Rough Rock Flags recorded by Miller 1986, the longest trail revealed was $500 \mathrm{~mm}$ in length. These were probably created in subaerially exposed sediment, necessary to maintain their steep sides and ridges (B), and reflect movement of the (bivalve) trace maker towards a receding waterline (see Fig. 9). 

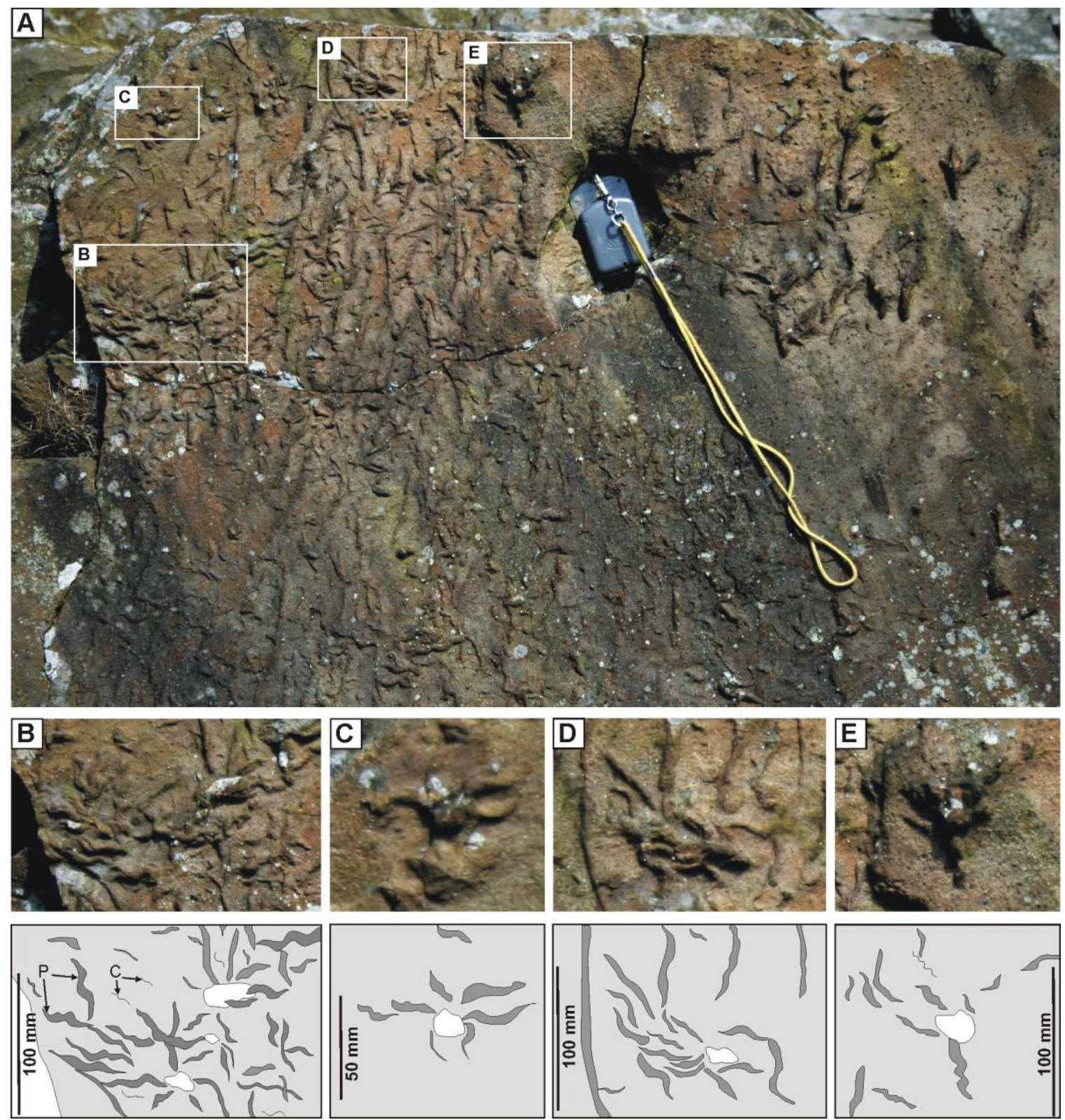

867

Figure 8 - Scavenging association typically includes Planolites, Cochlichnus,

868 Didymaulichnus and Palaeophycus. (A) Basal bedding plane of a fallen block. The 869 horizon from which the block fell is consistently marked by this ichnocoenoses and 870 overlies a thin $(100 \mathrm{~mm})$ siltstone interval, overlying which a relatively finer-grained 871 sandstone lens within the Rough Rock. Long traces are commonly aligned from the top to 872 bottom of the block, corresponding to ENE-WSW on the in-situ bedding planes; Hardy 873 (1970) recorded NW-SE orientated Coclichnus in the Rough Rock Flags. Insets B-E 874 show predominantly Planolites (P) and Cochlichnus (C) traces radiating towards central 875 hypichnial mounds interpreted to be Lockeia (pale grey colour), casts of dead and 876 decaying bivalves carried by flood waters to a previously quiet environment (e.g., a small 877 abandoned channel). 

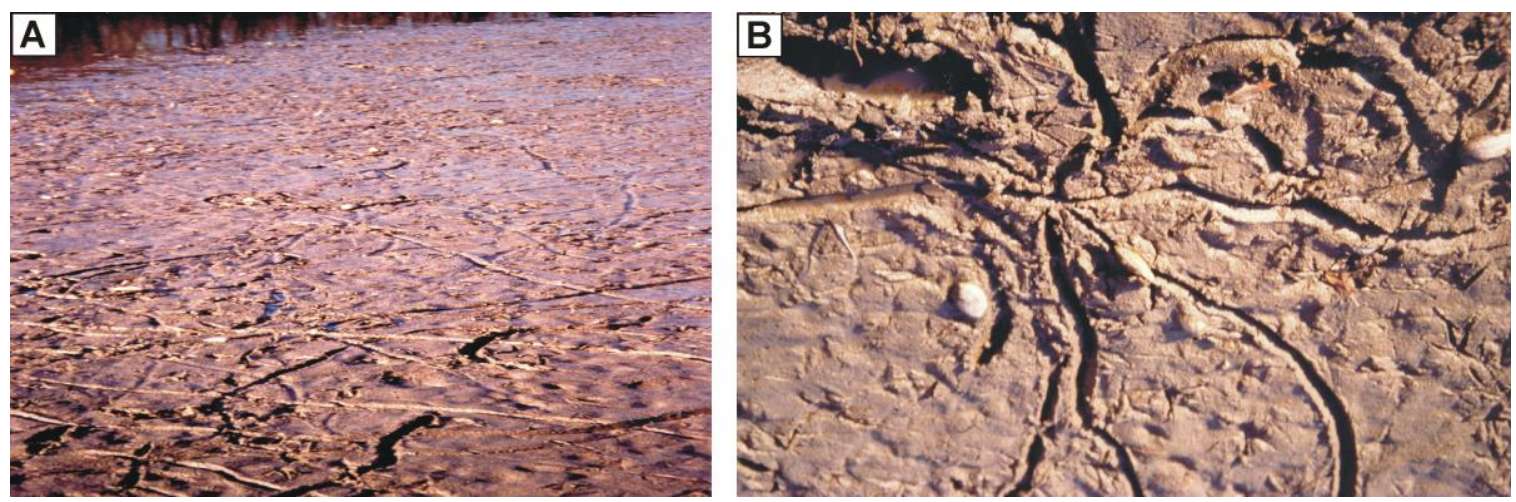

880 Figure 9 - Lateral movement traces (epichnial grooves) created by bivalves following a

881 receding water line during reservoir draining (Mapperley Reservoir, Derbyshire,

882 England). traces are generally sub-perpendicular to the receding water-line Photographs

883 courtesy of Dr Andrew Johnson.

884

885
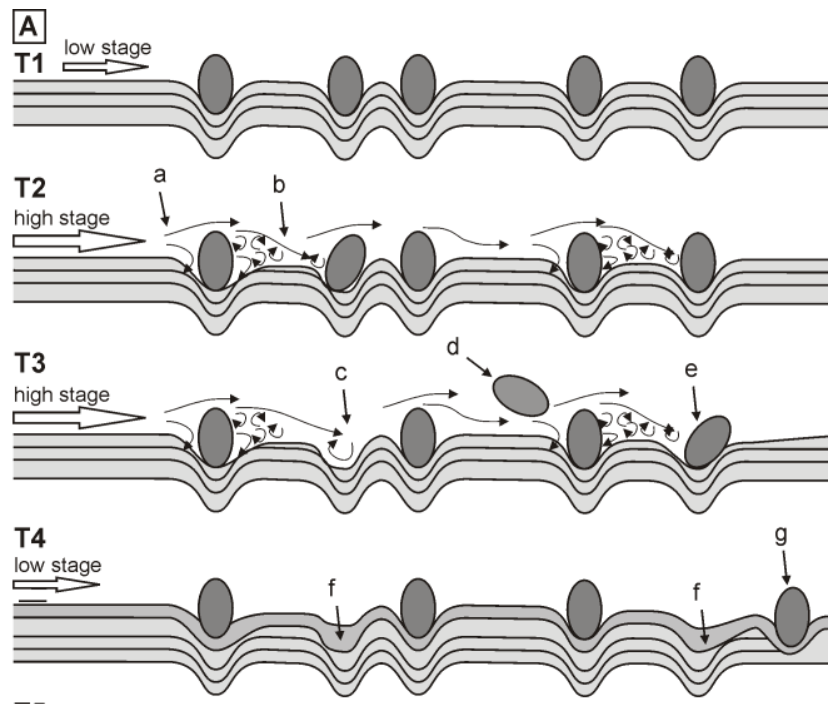

T5
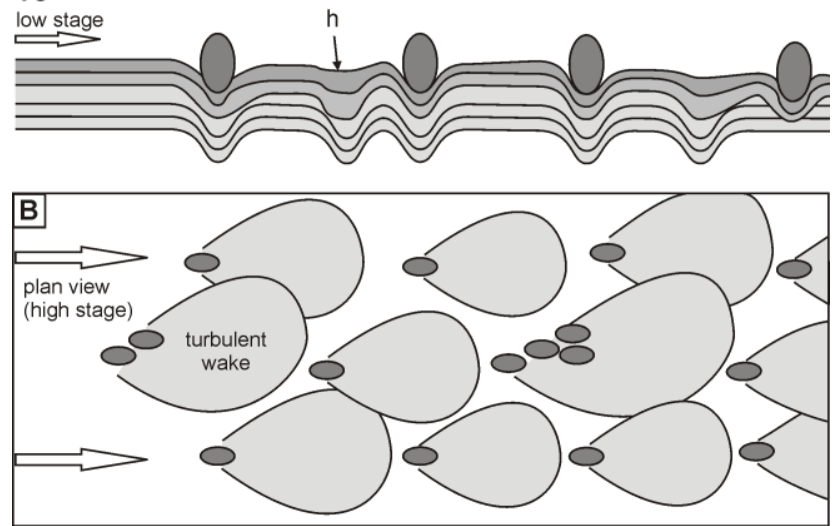

Figure 10 - A relatively regular spacing pattern of Lockeia has been noted. Evidence of erosion and scouring downstream of Lockeia has also been recorded. (A) A model is presented whereby erosion and scour associated with flow around individual, or clusters, 
891

892

893

894

895

896

897

898

899

900

901

902

903

904

905

906

907

908

909

910

creates a turbulent wake downstream of the organism. This turbulence leads to enhanced erosion and the destabilisation of bivalve in the immediate downstream vicinity. This mechanism may plausibly explain the relatively uniform spacing pattern of Lockeia often observed within the Rough Rock Flags and elsewhere. (a) steeper side to burrow on upstream side of bivalve; (b) deflation of sediment surface downstream of bivalve; (c) abandoned burrow, due to destabilisation associated with turbulent wake of upstream bivalve; (d) bivalve transported downstream; (e) bivalve destabilised within sediment; (f) ponding of sediment within hollow begins to heal the topography (compare to Fig. 5D); (g) bivalve relocated downstream (compare to Fig. 5C); (h) sediment surface nearly entirely healed (compare to Fig. 5D). (B) Plan view of the generation of turbulent wakes around individual or clusters of bivalves.

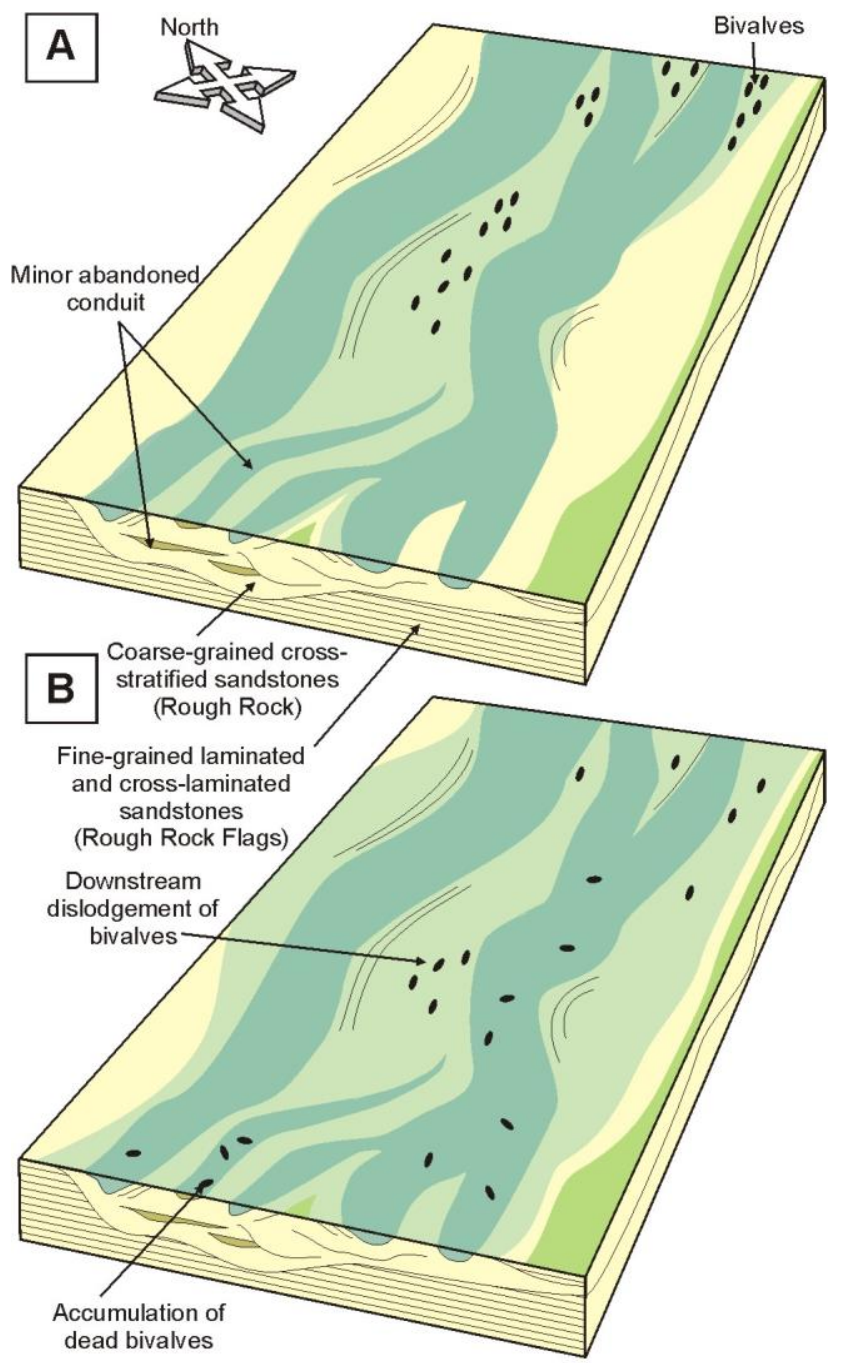

Figure 11 - Braided river setting of the Rough Rock during normal flow stage (A) and high stage (B). Bivalves are thought to have colonised areas of relatively lower energy flow, such as sand-flats developed on bar tops or crevasse splay areas. As such environments are prone to erosion, bivalves were periodically dislodged from their burrows and either managed to re-establish themselves soon after, or were transported down system, either being deposited in quieter areas, in this case a minor abandoned conduit, or transported further downstream. Dead bivalves deposited in these 
911 environments within the Rough Rock channel system were scavenged by polychaete and 912 nematode worms. In unidirectional flow regimes, bivalve year-classes may be transported 913 progressively further downstream, with the result that the oldest bivalve year classes may 914 be poorly represented in upstream localities.

915 